International Journal of English Literature and Social Sciences
Vol-6, Issue-2; Mar-Apr, 2021
Journal Home Page Available: https://ijels.com/
Journal DOI: $10.22161 /$ ijels

\title{
A Critical Analysis of the Creditors: A Play by August Strindberg
}

\author{
Aleena Hussain
}

Student, Bachelor of Science, English Language and Literature at Lahore Garrison University, Pakistan

Received: 25 Jan 2021; Received in revised form: 02 Mar 2021; Accepted: 02 Apr 2021; Available online: 28 Apr 2021

(C)2021 The Author(s). Published by Infogain Publication. This is an open access article under the CC BY license

(https://creativecommons.org/licenses/by/4.0/).

\begin{abstract}
August Strindberg, regarded as the rival of Henrik Ibsen, is hailed as the profound modernist drama playwright of Sweden. His work, Creditors (1888) was first performed in 1889 and depicts the deconstruction of marriage and the battle of the sexes. The framework of critical analysis was to draw out the themes and investigate characters, setting, style, and conflict of the play. The results indicated the themes of naturalism, feminism, vampirism, misogyny, aestheticism, moral decay, disillusionment, love and revenge. In this one-act play, the characters are well off financially but possess flaws of selfishness, moral degradation and suspicion. The analysis concluded the conflict of the play to be soliciting Tekla's love and the revenge inflicted by her former husband. The style of the play is a tragicomedy. This research can serve as counsel for future evaluation on Creditors or August Strindberg and is open for further study.
\end{abstract}

Keywords- August Strindberg, Creditors, critical analysis, naturalism, feminism, vampirism, tragicomedy, battle of the sexes.

\section{INTRODUCTION}

In this modern-day and age where several freedom and independents movements like the feminist and racial awareness movements are creating milestones, however there some writers of the past that still create a sense of impact with their striking works. One such writer is August Strindberg. August Strindberg is regarded as the profound modernist drama playwright of Sweden. He was a distinguished misogynist who was known to oppose plays considered feminist or credited with female empowerment like the A Doll's House by Henrik Ibsen (Lewis). His naturalistic plays deal with the unconsciousness of the characters which usually foreshadow the plot of the plays, as he emphasized that "people of today are most interested in the psychological process. Our inquisitive souls are not satisfied just to see something happen; we want to know how it happened. We want to see the strings, the machinery, examine the double-bottomed box, feel for the seam in the magic ring, look at the cards to see how they are marked." (Strindberg, 71).
One of his most memorable works, the Creditors (Swedish: Fordringsägare) was written in Denmark during the time of August and September of 1888 but was first published in February of 1889 in Danish and later in Swedish in 1890. On March 9, 1889, this play was first performed in Copenhagen at the renowned Dagmar Theatre.

My goal in this paper is to explore and examine the work of the Creditors by August Strindberg to find out the thematic tones, setting significance, character analysis and style incorporated by the playwright. For this literary investigation, the premise of critical analysis is applied.

To critically analyze the text explicitly and thoroughly, the exploration and scrutiny conducted of the play are divided into multiple sections, including characters, themes, style and setting analysis. The first section contains the literature review of the work under study. In the second and third sections, a summary of the play is provided along with the short biography of the playwright. The fourth section discusses in depth the traits and personality of the characters. A detailed analysis of the themes of the play is inspected after meticulous 
examination of the setting, style and conflict is conducted in the subsequent sections. The overall results of the detailed critical analysis are summed up in the conclusion of the research paper. This approach of breaking down the play into several segments is undertaken for the systematic and formatted analysis of the study.

\section{LITERATURE REVIEW}

The domestic and marital relationships exhibited in the plays of August Strindberg are a reflection of the conflicting and uncertain relationships between the partners. Most often than not, women are represented as maladjusted, having dividing and usurping natures that disrupt their relationships. The characters possess a detached and solitary personality that stems from a sense of dislocation. Noorbaksh Hooti (2011), explores the miasma of contradictions and malicious relationships in Strindberg's plays by closely examining a variety of his plays along with the biographical approach to the playwright's life. This paper deduces that only a mere pretext is required to tear down and expose the repressed violent and hostile temperaments of the characters. When this veil of courtesy is torn down, a wordy battle between the sexes compels one character to seek complete domination, supremacy and control over his or her emotionally weak counterpart. By the end of such heated combat, the mentally weaker character is left incomplete, maimed and emotionally distraught. According to Hooti (2011), this outward argument is a manifestation of the inner turmoil and conflicts of the characters for the fight to gain control within their associations. Within the play, Creditors (1898), a picture of bleak human connections is sketched. The married couple relates to each other as brother and sister, which is supposed to indicate the purity of their relationship, nevertheless, gets tainted with the notion of incest from a more critical angle. The wife is revealed to be more in control of the relationship, whereas this control over her husband resonants with vampirish and parasitic characteristics. Moreover, the character of Gustave falsifies his friendship with Tekla's husband to take revenge on his ex-wife; thus successfully tarnishing not only Tekla's reputation but also resulting in the death of Adolf. In this case, it becomes evident that friendship and friends have a stronghold over and can with ease contribute to the destruction of one's sense of identity. Hooti (2011) concludes that the contamination of relationships may result from personal conflicts and social transactions having pernicious intentions. This study expresses that unlike Strindberg's characters who become free only through the mode of death; we as human beings can unite without falling prey to inferiority and superiority complexes.

The earlier plays of Strindberg are laced with elements of naturalism and Darwin's determinism. The characters of Creditors all try to impose their perceptions wrapped up as weapons instrumented to impose their will on others. According to Szemerda (2013), the play is a fine deconstruction of marriage and the portrait of a sexual triangle that results in the fatality of the husband, aka Adolf. This play deals with the exploration of existentialism through the absence of the true world and the compelling feeling of valueness among the characters is finely showcased. The characters wield the sword of their individualistic perspectives and expression of the will to claim their version of the truth and thus to gain control and authority. The study surmises that Strindberg's drama is characteristically connected to existential and naturalistic philosophies that depict the battle of the sexes for power concentrated amid lust and disgust.

Reviewing the plot of Creditors in his book Studies in Strindberg (1998), Micheal Robinson highlights the naturalistic elements like the environment, heredity and the historical moment of the characters' lives that work towards the effectiveness of the theatre. In developing the natures of the characters, it can be rightly assumed that it is the form and not the set of the environment that plays a vital role in constructing the boundaries that confine them. The vivid ironic tone of the play depicts both the financial imagery and the conscience of the characters. The exceptional use of the words debit and credit symbolically represent and relate to the concepts of guilt and punishment. The semantics of payment and debt, and the settling of accounts closely resonate and relate the literary conceptions with that of the financial aspects; i.e morality and money, price and retaliation. Gustave, acting as paying off old scores and by taking revenge upon his ex-wife, in a sense balances the accounts and collects his dues. According to Robinson (1998), the sense of internalized guilt among the characters in this play emerge in the form of punishing transgression. This play illustrates that life and theatre are interconnected as the consecutive scenes that provide not only formal pleasure but also a sense of life as theatre. However, a critical analysis has not been done on the play which this paper aims to conduct.

\section{ANALYSIS \& DISCUSSION}

Johan August Strindberg was born on January 22, 1849, in Stockholm, Sweden and died on May 14, 1912. He was a prominent Swedish playwright, novelist, and short-story writer. His childhood is diffused with mental anguish, poverty, emotional instability, neglect and the 
religious zealotry of his grandmother. At first, Strindberg struggled with various unsuccessful jobs while he pursued a career in ministry and medicine. The rejection of his first play acted as a catalyst for his hatred for ceremonious traditions and formal institutions. Later on, his unhappy marriage and the loss of custody of his four children increased his affliction. He was charged with blasphemy after publishing his first volume of plays in 1884 but acquitted. Nonetheless, this incident took a toll on his mental health. He is notable for his works of The Father (1887), Miss Julie (1888), Creditors (1888), A Dream Play (1902), and The Ghost Sonata (1907). August Strindberg is credited for writing the first modern Swedish drama. His plays involve an amalgamation of psychology and dramatic naturalism and later on these evolved into expressionist drama. He vividly expresses the frauds and the ugly side of the Swedish society with biting satire and stern social criticism. His contempt for the social conventions and official institutions along with the battle of the sexes is boldly depicted in his work, thereby contributing to the European drama (Mortensen).

The play starts with Adolf residing and working on a sculpture in a beach hotel. He first professes his love for Tekla, then recounts her influence on him, and declares gratitude to Gustave for reviving his creative side. On prodding from Gustave, Adolf informs him of how unhappy he is in his marriage. He gave his loyal love, unconditional support and all material wants to Tekla but still, she treats him as his inferior. Gustave informs him of the downside of love, the miseries that come from being married to such a woman and the causes of epilepsy through selected words to dishearten Adolf from Tekla. It is revealed that Gustave was the first husband of Tekla, who left him in a dishonourable way to marry her lover, Adolf. Gustave is here to exact revenge from Tekla by undermining her marriage with Adolf. He does this by casting discriminating ideas inside Adolf's head and encouraging to deal with his wife sternly.

Tekla arrives from her social meeting and is confronted by her husband, meanwhile, Gustave observes this interaction from a hidden position. Adolf babbles out his frustration and fears in front of his wife. He accused her of wanting other men's attention, rejecting and disowning his support and love. The stubborn nature and boldness of Tekla further his suspicions of her. Outwardly he announces leaving the place for fresh air but quickly hides in the adjoining room to eavesdrop on Gustave and Tekla's discussion. Gustave makes his presence known to Tekla in the absence of her husband. He initiates a conversation reminding her of her peaceful and lovely past with him. He praises her and comments on her intelligence. All these actions of Gustave first have a hearty impact on Tekla who willingly flirts with him. To seduce Tekla, Gustave embraces her which is seen by two passing tourist women. This situation brings Tekla back to reality as she realizes her true love for Adolf and simultaneously denounces and calls out Gustave on his conniving schemes. Nonetheless, she is too late in her confession as Adolf, having heard everything has a seizure and dies in Tekla's arms. Gustave remains successful in his vindictive plan and starts to leave the scene having realized that Tekla loved both of them.

\section{Character Analysis}

To fully comprehend the actions and reactions of the characters, it is essential to understand their motivations, psyche, background and their viewpoints depicted through the roles they enact in the play. Within this play, the main characters include Adolf, Tekla and Gustave and the minor characters are two ladies and a porter.

Adolf is the husband of Tekla and an artist, a former painter and present sculptor. At the beginning of the play, he appears to be working on a wax figure and moving with the help of crutches. He repeatedly thanks and indicates gratitude towards Gustave, in the understanding that Gustave revived his artistic sense and woken the aesthetic qualities in him that Adolf thought were either lost or in permanent deep slumber. This repeated act of gratitude indicates Adolf's sense of gratefulness and being indebted to Gustave for uncovering the veil of false love from his eyes. He believes Gustave is a sincere friend of his who made him realize the reality of his marriage and the real ugly face of his wife, Tekla. He was the one who had comforted Tekla, bolstered her confidence and the strength to face the world. Adolf is gullible and dupable as first Tekla made him believe her love for her and then was exploited by the revenge-seeking Gustave through sweet talk and persuasive words. He musters up the courage to confront Tekla and is left disparaged at her tenacious and obstinate personality. He insists on going back home and leaves the room to hide in the adjoining room to spy on Tekla's meeting with Gustave. The overhearing declarations and expressions between Tekla and her former husband left him in a fit of epilepsy or heart attack resulting in his death. He dies believing Tekla, the love of her life, to be a deceitful woman.

Tekla is the current wife of Adolf and the former wife of Gustave, also the author of a book in which she ridiculed Gustave. She appears to have acquired "marital resemblance" (Strindberg 8) by using certain expressions picked from Gustave, this is one of the discords that Adolf harbours against her. It is conveyed that she learned to 
write, swim and how to be confident through Adolf. Through the eyes of Adolf and Gustave, Tekla appears to be a selfish, manoeuvring and conceited woman who only enjoys her own company and uses other people for her gains. However, Tekla does nothing to denounce their misconception of her being an "old flirt" (Strindberg 15) as she boldly started an affair, blatantly flirts with the youth on the boat, consistently subjects Adolf and admits rather "roguishly" (Strindberg 21) that "My heart is so big, little brother, that there is room in it for many more than him" (Strindberg 21). Her love is described to be something that "pulls and numbs" (Strindberg 13) Adolf who simultaneously loves and is afraid of her. This suggests the charisma, charm and strong nature of Tekla. Moreover, it also implied the stubborn and obstinate nature of Tekla. Towards the end of the play, while being unsuccessfully seduced by Gustave, she realizes her true love for Adolf and the deceptive game played by Gustave to trap her. This alludes to her mental acuteness of being an intelligent person who can see through the lies and deception of others. By the end of the play, Tekla is left alone as he loses her first husband to an affair and the second husband to death.

Gustave is the ex-husband of Tekla and is also a school teacher of old languages. He has come to befriend Adolf using a misleading identity. Under the guise of friendship, Gustave enacts revenge for the betrayal of trust through the extramarital affair of his former wife, Tekla and Adolf. He was portrayed as an idiot and ridiculed in Tekla's book. Gustave appears to be a very perceptive, sharp and keen observer of the human psyche. He not only falsely befriends Adolf without revealing his true identity and nature, he also subtly manipulates and exploits Adolf. He repeatedly prompts and taunts Adolf to undermine his marriage with Tekla, as Gustave hints at Adolf being a "chaperone" (Strindberg3) and toning down his voice under "the rule of the slipper" (Strindberg 4), casting clouds on his emotional security by questioning him on "And you have never wanted to be free?" (Strindberg 2) and "Which means that you are not entirely happy?" (Strindberg 2). Gustave plants the seed of doubt, unhappiness and suspicion between the relationship of Adolf with Tekla. Under the impression that it is his brother's story, he narrates the story of how he married a girl like Tekla, believing her to be an innocent angel but she usurped him and induced epilepsy in him. He presents excuses like under the umbrella of Indian ritual of widow burning and all human race being distantly related to justify himself whenever Adolf even comes close to dissecting his true identity. He puts sharp words in Adolf's mouth and conflicting images in his head regarding the infidelity of Tekla. He observes from an adjoining room the confrontation between the couple and comes out to manipulate and seduce Tekla in the absence of her husband. He exacts his revenge in the form of portraying her as a despicable woman to Adolf and though Adolf's death, he concludes that Tekla loves both of them. He is a master manipulator and a person empty of feelings. All he concentrates is on how the society mocked and belittled him on the affair of Tekla, therefore he devises strategies like a chess player to break the bond between Tekla and her current husband through the use of deluding and misleading words. Tekla rightfully sums up his personality in the words of "tact and politeness" (Strindberg 31).

The two ladies are dressed in travelling dresses and appear to be tourists. They are only mentioned as spectators passing on the veranda of the hotel. They view and judge Gustave and Tekla in an embrace in passing the corridor through the open door. These women represent the society and the world who have witnessed the scandalous scene of Tekla, a married woman embracing someone who is not her husband.

The porter is summoned by Gustave to bring his bill as he wanted to depart from the eight o'clock boat.

\section{Setting Analysis}

The setting is an essential element of the play as it is the place where all the action and the plot of the play takes shape. The characters gather at this place and provide the narrative. This is the element that allows the audience to visualise the context and the action of the play. The setting of this play is of a summer hotel near a sea-shore. A view of the landscape is visible from a door leading to the veranda. This scene indicates that the characters are wealthy and can afford the material luxury of residing at a beach hotel. The room or the parlour of the hotel contains minimalist furniture and props indicating the focus of the playwright on the characters and the narrative. There is a table in the room along with a sofa and a chair. A newspaper can be seen on a table stand near the door indicating that the characters are educated and well informed of the world around them. There is a miniature modelling stand holding a wax figure displaying the artistic nature and talent of the character of Adolf.

\section{Thematic Analysis}

The theme is the central idea of the story and the concept around which the narrative is set. This play revolves around several distinct conceptions ranging from feminism, aestheticism and naturalism. The themes not only incorporate these abstract conceptions but also shed light on the varying discussions within the play that stress female values, vampirism, the creativity of the artist, deception and love in the wake of the breakdown of a marriage. 
At times the experiences and thought processes of the playwright not only bring out but also dictate the themes of the play. August Strindberg's relationships with his parents, grandmother and later on with his wife were swarmed with anxiety, uneasiness and hostility. He had an unhappy marriage and later on lost custody of his children which impacted negatively on him. He took a break from writing and battled with madness for several years. All of this anguish and aversion to the females of his life can be elusively viewed in this play in the form of Tekla's hubris and indulgent character.

Feminism is a stark theme of Creditors where the intelligence, sharpness and independence of Tekla are highlighted. Tekla is a woman who is unafraid to take matters into her own hands. She is unafraid to own and voice her sexuality, selfishness, misdeeds and confesses her true feelings to Adolf by the end of the play. She is a strong woman who not only escapes the clutches of her hollow marriage with Gustave but also marries Adolf and owns up to her misdeeds. She is an author of a successful book on her ex-husband, displaying her talent without any disregard for societal rules. She matures throughout the play from being a covetous and an egomaniac to a redeemed person.

Throughout the play, Gustave and Adolf accuse and label Tekla as a controlling, manipulating and an "independent nature" (Strindberg 1) woman who restricts and blocks the freedom of her husband, Adolf. According to them, Tekla is someone who cannot be trusted or granted any kind of room for freedom. This is apparent from the dialogues of Adolf saying, "No, she stopped growing and I pushed on" (Strindberg 2) and "Ridiculous? Can a man be ridiculous because he trusts his wife?" (Strindberg 3). Gustave repeatedly stacks misogynistic claims against the strong-willed character of Tekla by interpreting and undermining the motives of the marriage of Tekla, as he states "However, the first husband was a tyrant, and she took him only to get her freedom. You see, a girl cannot have freedom except by providing herself with a chaperon - or what we call a husband" (Strindberg 3). This misogynistic element of the play develops from August Strindberg's poor relationships with women. His dismantled depiction of women indicates women to be starved for attention and credence, usurpers of others' time and efforts, horrible caricatures of men that they are by nature and "incomprehensible, sphinx-like" (Strindberg 12) beings devoid of authentic thought and knowledge. The phrase "For a woman is never admired by other women" (Strindberg 24) uttered by Tekla when admits liking male attention further strengthens this conception. It is applied that women, in general, are pitted against each other and tend to look towards male encouragement and admiration for self-satisfaction.

In aestheticism, the artwork is considered good or bad depending upon its virtual characteristics that are being graspable by the sense of sight or hearing (Shelley). At the start of the play, Adolf puts on a face that all of his creativity and artistic sense arises from the love and presence of his wife, but as soon as she leaves him alone for a while, he becomes depressed and loses his creativity. However, this presumption of Adolf is untrue as he recovers his artistic sense and starts work on a wax model as he utters, "The desire to work and the instinct for creation came back" (Strindberg 1). This indicates that the desire to create, fashion and sculpt is innate and inherent in Adolf. Adolf himself contradicts this conception that Tekla was his inspiration and his virtual sight through which he constructed good sculptors. Adolf in the veracious sense is an artist who never stops to critically analyze or dissect whether be it relationships or events of his life as he admits, "You live with a woman for years, and you never stop to analyse her, or your relationship with her, and then-then you begin to think" (Strindberg 4).

To undermine Tekla's talents, Gustave questions the poetic nature of her work and how it lost its charm and improvements after writing about the only inspiration of her life, her first husband; in the words of "Yes, isn't it strange that her "authoring" seemed to fall off after her first book-or that it failed to improve, at least?" (Strindberg 2). As the play progresses, it becomes clear that Adolf was once a painter but he downplayed his talent in front of Tekla to boost her confidence in writing. This act of downplaying was so convincing and repeated that Adolf himself lost the ability to paint, suggesting that aestheticism is only through the powers of belief, sight and faith.

This play incorporates the concept of naturalism in it as the characters reject scientific notions and focus on their congenital, instinctive and intuitive natures. Tekla follows the desires and self-interests as she first pursues Adolf while still being married to Gustave. Later she befriends all of Adolf's acquaintances leaving him socially abandoned and finally flirts with Gustave. However, she soon realizes the error of her ways and her true love for Adolf and this realization stems from epiphany and subconsciousness. Adolf on the other hand professes his sincere love for Tekla but comes to doubt his wife's actions. He sets up a trap to test Tekla's loyalty for him and in the process becomes heartbroken.

It is part of human nature that one never stops inspecting the circumstances and people in life, as Adolf admits "you never stop to analyse her, or your relationship 
with her" (Strindberg 4). After being too much attached and hooked with the presence and nature of Tekla, Adolf realizes the need for male bonding as Gustave reminds him of his "craving for masculine company" (Strindberg 1). Humans are gullible beings that can be easily swayed by love or manipulation as in the case of Adolf. He is jealous and disturbed at the coquetry of Tekla and obsesses over the notion that Tekla will leave him one day which will result in the satisfaction of her former husband. This obsession and thought signal the presence of abandonment fears in him.

Humans by nature are egoist beings as they constantly seek to uplift their reputation and face through any means possible. With quite a difficulty and coercion from Gustave that Tekla realizes her love for Adolf to be true, as before she was quite adamant and obstinate on her opinions of dallying with the youth to secure her ego. Gustave was derided by the issue of Tekla's infidelity that to augment his lost pride and downtrodden ego, he had to seek vengeance from her.

In this misogynistic portrayal of Tekla's character, there is an implication of vampirism and parasitism as Tekla first absorbed all of Gustave's energy and discarded him for Adolf. Later on, she sucks out the creative tendencies of Adolf and along with his sense of trust and loyalty for her. She leaves him friendless and heart rendered in her pursuit of self-satisfaction. She used Adolf to educate herself, build her social status and in this process, it appears as if she seized and wrested the confidence, "eating your soul, your courage, your knowledge" (Strindberg 10) of Adolf. Tekla is portrayed as a parasitic leech that sucks out the vibrancy and spirit of those close to her and leaves them empty, bitter and scorned. This sense of vampirism is apparent from the dialogues of Adolf and Gustave respectively; "It almost seemed to me as if she had actually taken my courage away from me" (Strindberg 10) and "But nevertheless she managed to usurp the male prerogative -" (Strindberg 5).

The theme of love, lies, moral corruption and betrayal of trust through extramarital affairs is also present in the play. Adolf appears to be madly in love with Tekla and he states that he cannot live without her and constantly longs for her; as he declares "It is queer that sometimes I have a feeling that she is nothing in herself, but only a part of myself-an organ that can take away with it my will, my very desire to live" (Strindberg 2). Tekla and Adolf deceive Gustave while he is away and gets married. This leaves Gustave embittered, vindictive and grudge-bearing. Gustave sets out to dishonestly befriend Adolf under a false identity, manipulating and deceiving both Tekla and her husband to the point where his actions result in the death of the gullible Adolf. Moreover, the concept of love in this play is distorted as love according to them is only for the present and available bodies. Gustave, based on his experiences, judges a "woman's love consists in taking, in receiving," (Strindberg 8 ) and "By comparison the absent one seemed to fade out" (Strindberg 8). This statement not only indicates the twisted and contorted sense of love he possesses but also is in opposition to the intangible love of a woman.

Throughout the play, Adolf faces a midlife crisis as he struggles with his creative side and casts doubts on his wife's love. He becomes disillusioned with the prospect of love and begins to view Tekla through the eyes of Gustave. This disillusionment is manifested when "he tears it up and flings the pieces under the table" (Strindberg 18) the picture of Tekla and takes up the position to confront her. However, this process of disillusionment leads Adolf to his death.

Style Analysis

The style of the play is a tragicomedy. The tragicomedy comprises both elements of tragedy and comedy, and Shakespeare made this style quite popular (The Editors of Encyclopaedia Britannica). A tragicomedy was first written by the Roman playwright Plautus and the purpose of this style is to probe and examine the vastness of human experience and nature, and to pique laughter and pleasure in between the scenes of sorrow (Tragicomedy).

There is an absurd mirth developed through the conversation of Adolf and Gustave when they are breaking down the foundations of Adolf's marriage and biasedly initiating a campaign against Tekla. The persuasive expressions, false stories of epilepsy and highlighting the superstitious ritual of Indian satti to convince Adolf of the faithlessness of Tekla by Gustave comes across as being humorous. Remarkably, Gustave can narrate the tale of the injustice done to him by his ex-wife and her lover, with quite ease and calm although this was the terrible reason for enacting retribution.

Addressing each other as "brother and sister" (Strindberg 9) by Tekla and Adolf, although being legally married to each other is a source of slapstick humour. There is dark meaning and tragedy to their address, as it hints at how their affair and marriage was brought about by deceiving Gustave and the world in general of being innocents.

The stubbornness of Tekla and her teasing manner along with being easily led astray by Gustave appears comic in a way. However, all these outwardly comic scenes lead to the tragic death of Adolf, cruel revenge of Gustave and Tekla being left all alone by the end of the play. 
The style of the play is a one-act play. All of the action of the plot revolves around in one setting and in one scene or one act. Adolf and Gustave paint the ugly picture of Tekla in a parlour room, the confrontation between Tekla and her husband occurs in the very same setting. Towards the end of the play, Gustave exacts his revenge on his former wife in the same room and Adolf also dies tragically in the same setting and same act. This also suggests that there is no change in the setting of the play.

\section{Conflict Analysis}

The conflict of the play is the underlying problem or issue that the plot is centred on. It is to be addressed and resolved by the characters. In this play, the conflict of the play is the Tekla's love that is faced, desired and feared by her both former and current husband. The conflict arises with Gustave manipulating and encouraging Adolf to confront Tekla and the actions of Gustave to strike a reprisal against Tekla by breaking down her marriage.

Both Adolf and Gustave are madly in love with and both harbour the feelings of being played, used and deceived by Tekla. Both want and yearn for her love and attention. When they fail to achieve this desire, they turn to discredit and malign her character.

Adolf who starts to be in a dilemma of love and hatred for Tekla gets disillusioned by the end of the play and a result dies. On the other hand, Gustave, who is betrayed by Tekla, sets out to recriminate and exact revenge from her by manipulating her Adolf and trying to seduce her. Although he achieves his retaliation against her but is still left lonely and brimmed with rancorous thoughts and does not find peace.

Tekla, who is confident in her abilities and power of love, is left alone with selfishness as Gustave leaves her and her husband dies in her arms.

\section{CONCLUSION}

The critical evaluation of play Creditors by August Strindberg from the standpoints of setting, character, style, conflict and thematic analysis reveal the psychological aspects of the characters. The characters appear to be financially well but lack in terms of moral convictions. They are bent on self-serving needs and seek revenge and acceptance through others. The play is one-act and is a tragicomedy in nature. The themes concluded through the analysis are naturalism, aestheticism, feminism, misogynism, identity and midlife crisis, love and betrayal, vampirism, disillusionment and moral corruption. The conflict arises from the motivation of Gustave to seek revenge against his former wife.
The first considerable limitation of this research paper is that only the frame of critical analysis was incorporated. This research is open for further study.

Through the conducted research it is recommended that this research paper may be taken as an example for future work involving critical analysis style. Moreover, this paper can be used as information for any further study on the play, Creditors or on the author, August Strindberg.

\section{REFERENCES}

[1] Hooti, Noorbakhsh. "The Miasma of Contradictions and Malicious Relationships in Strindberg's Plays: A Biographical Approach.” Journal of Language, Technology \& Entrepreneurship in Africa, vol. 3, no. 1, 2011, pp. 5467, file:///C:/Users/hi/Downloads/66587-Article\%20Text134485-1-10-20110525.pdf. Accessed 18 January 2021.

[2] Lewis, Pericles. "August Strindberg." Campuspress.com, https://campuspress.yale.edu/modernismlab/auguststrindberg/. Accessed 7 January 2021.

[3] Mortensen, Brita Maud Ellen. "August Strindberg." Britannica, Encyclopaedia Britannica, 10 May 2021, https://www.britannica.com/biography/August-Strindberg. Accessed 6 January 2021.

[4] Robinson, Michael. Studies in Strindberg. London, Ubiquity Press, Norvik Press, 1998, https://www.jstor.org/stable/j.ctv3t5rfk. Accessed 15 December 2020.

[5] Shelley, James, "The Concept of the Aesthetic", The Stanford Encyclopedia of Philosophy (Winter 2020 Edition), Edward N. Zalta (ed.), URL = <https://plato.stanford.edu/archives/win2020/entries/aesthet ic-concept/>. Accessed January 18, 2021.

[6] Strindberg, August. Plays by August Strindberg: Creditors. Pariah. Translated by Edwin Björkman, New York, C. Scribner's Sons, 1912. Project Gutenberg, https://www.gutenberg.org/files/5053/5053-h/5053h.htm\#link2H_4_0003. Accessed 06 January 2021.

[7] Szemerda, Karolina. "The truth behind the door Strindberg and existentialism." Edited by Paul Hollywood. Bachelors Final Year Project, Dublin Business School., 2013. Esource. Dublin Business School, https://esource.dbs.ie/handle/10788/1270?show=full.

Accessed 15 December 2020.

[8] The Editors of Encyclopaedia Britannica. "Tragicomedy." Britannica, Encyclopadia Britannica, 25 August 2014, https://www.britannica.com/art/tragicomedy. Accessed 08 January 2021. 